Editorial

\title{
Ethos Cultural, portadores de deficiência física e publicações cientificas
}

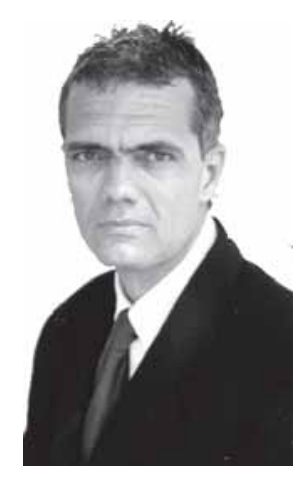

M aro A ntonio G uimarães da Silva,M ed.D r.Sci. marø@ atlanticaedu.com.br

Curioso com o fato de que, nesses seis anos de existência com quase 500 artigos publicados, não havia indicação de que temas relacionados a pessoas portadoras de deficiências tivessem merecido lugar em nossa revista, resolvi buscar uma explicação com o editor executivo. Talvez ele me pudesse explicar o estranho fato.

O nosso editor executivo, um francês, médico por profissão e jornalista e filósofo por vocação, com algumas obras publicadas em sua terra natal e uma longa experiência na área de edições científicas, apesar de sua eclética formação, também não foi capaz de justificar o fato, o que me levou a refletir sobre a questão.

A falta de publicações sobre portadores de deficiências talvez seja um indicativo de que o fato ainda não ganhou a dimensão que merece. 0 problema pode ser encarado sob diversos prismas. Contudo, no que se refere à escassez dessas publicações, é possível levantarmos algumas suposições: há trabalhos de pesquisas sobre 0 assunto, mas seus autores não se preocupam em publicar; os centros de reabilitação geradores de trabalhos científicos são em escasso número, e os trabal hos ali produzidos se pulverizam nas revistas; os que fazem o trabalho na área não estão engajados com 0 espaço acadêmico; ou, uma última hipótese, não se faz trabalho na área. Imagino que alguns desses fatores podem coexistir e acabam por expressar o que pode estar ocorrendo na área de atendimento às pessoas portadoras de deficiência.

Resolvo, então, tentar entender e melhor dimensionar o fato. As fontes que possuo sobre o tema estão amparadas, sobretudo, pela III Conferência Intergurbernamental I beroamericana sobre Políticas para Adultos $M$ ayores y Personas com Discapacidad (Estatutos de la Red Iberoamericana de Cooperación Técnica. M adrid. M inistério de A suntos Sociales; 1994:19-25).

Segundo a Organização M undial da Saúde, cerca de 10\% da população mundial apresenta al gum tipo de incapacidade. O s dados estatísticos da OM S são al gumas vezes questionados e a sua verificação está sujeita a múltiplas limitações. Sabe- se, entretanto, que as variações regionais podem ser muito importantes e em algumas áreas geográficas superariam em muito as taxas da OMS. Os dados prospectivos para a A mérica Latina, realizados na década de 90 para o final do século XX, apontavam para uma variação de 53 a 85 milhões de pessoas com algum tipo de incapacidade. Está clara a associação entre incapacidade e pobreza, com a agravante de que a maioria desses núcleos fica à margem dos serviços de atenção de saúde e somente uns $2 \%$ da população incapacitada da A mérica Latina recebe atenção sanitária adequada.

U ma extensa lista poderia justificar as incapacidades, mas, sem dúvida, os acidentes em casa, os acidentes de trânsito, as enfermidades de todo o tipo, além das seqüelas de conflitos armados podem representar constituir as causas mais relevantes.

N o Brasil, o decreto no 3.298 , de 20 de dezembro de 1999, regulamenta a Lei no 7.853 , de 24 de outubro de 1989, que dispõe sobre a política nacional para a integração da pessoa portadora de deficiência, consolidando as normas para a sua proteção além de outras providências. 0 artigo $n$. 4 do decreto, em seu item I, que se relaciona mais diretamente com a fisioterapia, define o deficiente físico, considerando a pessoa portadora de deficiência como a que se enquadra nas seguintes categorias:

I - deficiência física - alteração completa ou parcial de um ou mais segmentos do corpo humano, acarretando o comprometimento da função física, apresentando-se sob a forma de paraplegia, paraparesia, monoplegia, monoparesia, tetraplegia, tetraparesia, triplegia, triparesia, hemiplegia, hemiparesia, amputação ou ausência de membro, paralisia cerebral, membros com deformidade congênita ou adquirida, exceto as deformidades estéticas e as que não produzam dificuldades para o desempenho de funções;

Os decretos-lei assinados, as cartas de intenções e de apoio de órgãos internacionais e as dezenas de milhares de associações que tratam do tema sugerem que o problema 
324

Fisioterapia Brasil-Volume6-Número 5-setembro/outubro de 2005

deveria ser alvo de grande atenção e, portanto, melhor equacionado. Já sabemos que isso não acontece. Onde estaria a origem de tal omissão?

$N$ ão encontrando culpados, resolvo transferir a discussão para a maneira como nós sedimentamos o nosso nível sóciocultural ao longo dos séculos. N essa direção, não há como deixar de abordar a colonização na A mérica L atina.

Durante os séculos XV, XVI e XVII os países que nos colonizaram, Portugal e Espanha, foram centros hegemônicos, cujos declínios se iniciam nos séculos XVI e XVII. O declínio dos colonizadores acabou por deixar as colônias sem um referencial e praticamente entregues a si mesmas. 0 modelo social que então se cria é fortemente amparado por uma diversificação cultural que apresenta diversas combinações que coexistem antagonicamente: codificadas e caóticas; eruditas e populares; oficiais e ilegais.

Como sugere o sociólogo português Boaventura Souza Santos, a prática social nos paises da A mérica L atina, baseada em uma profunda e enraizada mestiçagem, acaba por ser considerada a base de um ethos cultural tipicamente latino americano, que se arrasta desde o século XVII até hoje.

Exemplos atuais desta herança podem ser vistos, muito claramente, no comportamento indecente dos políticos; na institucionalização de propinas; na corrupção e no suborno que ocorrem em todas as esferas do serviço público; na passividade com que nós cidadãos encaramos todos esses desmandos e, obviamente, em nossa própria atitude de insistir em eleger tão mal aqueles que nos representam nas diversas esferas.

Há ainda uma última hipótese ainda não levantada por mim. A de os portadores de deficiências recebem tratamento à altura e que existem no Brasil muitíssimos trabalhos de pesquisa e publicação na área discutida, que não chegam aos nossos editores. $N$ este caso, terei cometido neste editorial a maior das heresias sociológicas jamais vista. Todos torcemos para que esta hipótese seja verdadeira. 